\title{
IMPLEMENTASI MANAJEMEN PEMBELAJARAN TERHADAP KONSEP DIRI DAN PRESTASI AKADEMIK MAHASISWA SEMESTER VIII SEKOLAH TINGGI ILMU KESEHATAN AISYAH PRINGSEWU
}

\author{
$\underline{\text { Aprilia Triaristina }}$ \\ Sekolah Ilmu Kesehatan, Ilmu Kesehatan Aisyah Pringsewu, \\ Email: liaforkia@gmail.com
}

\begin{abstract}
A professional health worker can be established through an educational process. Students and education are two inseparable things. The quality of students can be seen from the academic achievement he achieved. Academic achievement is a change in behavioral skills or abilities that can increase over time that is not due to the growth process, but the existence of learning situations. So it is seen as proof of effort obtained by students. The number of samples in this study was 47 people. The results showed that. Most of the respondents who have self-concept in positive category are 31 respondents (65,9\%), where there are 26 respondents $(83,9 \%)$ got good academic achievement, and 5 respondents $(16,1 \%)$ got poor academic achievement, And only 16 respondents (34.1\%) have negative self concept, where as many as 7 respondents (43.8\%) got good academic achievement, and as many as 9 respondents (56.2\%) got poor academic achievement.
\end{abstract}

\begin{abstract}
Abstrak
Tenaga kesehatan yang profesional, dapat dibentuk melalui suatu proses pendidikan dan manajemen pembelajaran. Mahasiswa dan pendidikan merupakan dua hal yang tak terpisahkan. Kualitas mahasiswa dapat dilihat dari prestasi akademik yang diraihnya. Prestasi akademik merupakan perubahan dalam hal kecakapan tingkah laku ataupun kemampuan yang dapat bertambah selama beberapa waktu yang tidak disebabkan proses pertumbuhan, tetapi adanya situasi belajar. Sehingga dipandang sebagai bukti usaha yang diperoleh mahasiswa.Jumlah sampel dalam penelitian ini adalah 47 orang. Hasil penelitian menunjukkan bahwa.sebagian besar responden yang memiliki konsep diri dalam kategori positif yaitu sebanyak 31 responden (65,9\%), dimana terdapat 26 responden (83,9\%) mendapat Prestasi Akademik baik, dan 5 responden $(16,1 \%)$ mendapat Prestasi Akademik kurang baik, dan hanya 16 responden (34,1\%) yang memiliki konsep diri negatif, dimana sebanyak 7 responden (43,8\%) mendapat Prestasi Akademik baik, dan sebanyak 9 responden (56,2\%) mendapat Prestasi Akademik kurang baik.
\end{abstract}

Kata kunci: Manajemen Konsep Diri, Prestasi Mahasiswa 


\section{A. PEndahuluan}

Kesehatan adalah hak asasi manusia dan sekaligus investasi untuk keberhasilan pembangunan bangsa. Untuk itu diselenggarakan pembangunan kesehatan secara menyeluruh dan berkesinambungan, dengan tujuan guna meningkatkan kesadaran, kemauan dan kemampuan hidup sehat bagi setiap orang agar terwujud derajat kesehatan masyarakat yang setinggi-tingginya. Tinggi rendahnya derajat kesehatan masyarakat sangat dipengaruhi oleh faktor lingkungan, perilaku, pelayanan kesehatan yang meliputi sarana prasarana, dan tenaga kesehatan (SisKesNas, 2004).

Tenaga kesehatan adalah setiap orang yang mengabdikan diri dalam bidang kesehatan, serta memiliki pengetahuan, keterampilan melalui pendidikan dibidang kesehatan yang untuk jenis tertentu melakukan kewenangan untuk melakukan upaya kesehatan. Tujuan tenaga kesehatan adalah menghasilkan tenaga kesehatan yang profesional, memiliki kemampuan dengan orang lain, bekerja dengan berat, dapat dipertanggung jawabkan secara akademik menggunakan wewenang secara aktif dan bijaksana serta mampu berperan sebagai perencana, pelaksana dan penggerak pembangunan.

Perawat dan Bidan merupakan bagian dari tenaga kesehatan. Sesuai dengan tujuannya pendidikan kesehatan merupakan bagian dari pelayanan kesehatan yang tidak dapat dipisahkan, meliputi seluruh aspek yang ada dalam diri individu, keluarga, kelompok, dan masyarakat, bukan hanya memberi pelayanan kepada orang sakit saja, tetapi orang yang sehat menjadi target sasaran, dan untuk menciptakan tenaga kesehatan yang handal maka dapat pula didukung oleh institusi pendidikan kesehatan.

Tenaga kesehatan yang profesional, dapat dibentuk melalui suatu proses pendidikan. Mahasiswa dan pendidikan merupakan dua hal yang tak terpisahkan. Kualitas mahasiswa dapat dilihat dari prestasi akademik yang diraihnya. Prestasi akademik merupakan perubahan dalam hal kecakapan tingkah laku ataupun kemampuan yang dapat bertambah selama beberapa waktu yang tidak disebabkan proses pertumbuhan, tetapi adanya situasi belajar. Sehingga dipandang sebagai bukti usaha yang diperoleh mahasiswa.

Prestasi akademik masih mejadi tolak ukur kompetensi mahasiswa di bidang ilmunya. Oleh karena itu, banyak institusi kerja yang menggunakan indeks prestasi akademik mahasiswa untuk penerimaan karyawan. Namun kenyataannya, banyak mahasiswa yang memiliki prestasi akademik rendah (Sumargi,2008).Faktor yang dapat mempengaruhi keberhasilan dalam prestasi akademik ada 4 yaitu :Konsep Diri, locus of control, kecemasan, dan motivasi hasil belajar (Soemanto, 2006).

Secara umum, konsep diri adalah semua tanda, keyakinan, dan pendirian yang merupakan suatu pengetahuan individu tentang dirinya yang dapat memengaruhi hubungannya dengan orang lain, termasuk karakter, kemampuan, nilai, ide, dan tujuan (Alimul, 2009). Konsep diri akan memberikan kerangka acuan yang mempengaruhi manajemen diri terhadap situasi dan terhadap orang lain. Konsep diri ada yang sifatnya positif dan negatif. Individu yang memiliki konsep diri negatif meyakini dan memandang dirinya lemah, tidak dapat berbuat, tidak kompeten, gagal, tidak menarik, tidak disukai dan kehilangan daya tarik terhadap hidup. Individu akan cenderung bersikap pesimistis terhadap kehidupan dan kesempatan yang dihadapinya. Sebaliknya individu dengan konsep diri positif akan mampu menghargai dirinya dan melihat hal-hal positif yang dapat dilakukannya demi keberhasilan dan prestasi. Sehingga dalam kepentingan prestasi, kemajuan dan perkembangan, konsep diri mempunyai peranan yang signifikan. Signifikannya tindakan manusia erat kaitannya bagaimana manusia mendefenisikan dirinya.

Proses pembelajaran tidak mudah seperti membalikan kedua telapak tangan. Semua memerlukan rangkaian kaidah dan prinsip yang harus dilalui dalam melaksanakan kegiatan belajar mengajar dalam tenda-tenda pendidikan. Prinsip pembelajaran dalam dunia pendidikan dilahirkan dari rahimnya teori psikologi belajar. Oleh karena itu dalam prinsip pembelajaran ini lebih melihat dan menatap pada pengembangan aspek psikologis diri siswa yang dianggap memiliki serpihan kelemahan dalam belajar. Melihat kenyataan ini, maka prinsip manajemen pembelajaran dalam kancah pendidikan dianggap mampu untuk membangkitkan keterpurukan pembelajaran yang selama ini dianggap masih tertidur dan bermimpi.

Dari kenyataan ini, Fillbek seorang pakar pendidikan yang perduli terhadap pengembangan pembelajaran ini, mampu melahirkan indahnya gagasan tentang prinsip pembelajaran, yang kemudian disunting Siregar dan Nara (2010: 14), dan berkata; prinsip manajemen pembelajaran seperti yang tertera pada hal-hal berikut ini: 1.Respon-respon baru (new responses) diulang sebagai akibat respon yang terjadi sebelumnya. Implikainya adalah perlunya pemberian umpan balik positif dengan segera atas keberhasilan atau respon yang benar dari siswa; siswa harus aktif membuat respon 
tidak hanya duduk diam dan mendengarkan saja. 2. Perilaku tidak hanya dikontrol oleh akibat dari respon, tetapi juga dibawah pengaruh kondisi atau tanda-tanda di lingkungan siswa. Implikasinya adalah perlunya menyatakan tujuan pembelajaran secara jelas kepada siswa sebelum pelajaran dimulai, agar siswa bersedia belajar lebih giat. Juga penggunaan berbagai metode dan media agar dapat mendorong keaktifan siswa dalam proses belajar. 3 . Perilaku yang ditimbulkan oleh tanda-tanda tertentu akan hilang atau berkurang frekuensinya bila tidak diperkjuat dengan akibat yang menyenangkan. Implikasinya adalah; pemberian isi pembelajaran yang berguna pada siswa di luar ruangan kelas dan memberikan timbal balik (feedback) berupa penghargaan terhadap keberhasilan siswa. Juga siswa sering diberikan latihan dan tes agar pengetahuan, keterampilan dan sikap yang baru dikuasainya sering dimunculkan pula. 4. Belajar yang berbentuk respon terhadap tanda-tanda yang terbatas akan ditransfer kesituasi lain yang terbatas pula. Implikasinya adalah pemberian kegiatan belajar kepada siswa yang melibatkan tanda-tanda atau kondisi yang mirip dengan kondisi dunia nyata. Juga penyajian isi pembelajaran perlu menggunakan berbagai media pembelajaran seperti; gambar, diagram, film, rekaman/video, komputer serta berbagai meotode pembelajaran seperti; simulasi, dramatisasio dan lain sebagainya. 5. Belajar menggeneralisasikan dan membedakan adalah; dasar untuk belajar sesuatu yang kompleks seperti yang berkenaan dengan pemecahan masalah. Implikasinya adalah perlu digunakan secara luas bukan saja contoh-contoh yang positif, tetapi juga yang negatif. 6. Situasi mental siswa untuk menghadapi pelajaran akan mempengaruhi perhatian dan ketekunan siswa selama proses siswa belajar. Implikasinya adalah pentingnya menarik perhatian siswa untuk mempelajari isi pembelajaran. Antara lain; dengan menunjukan apa yang akan dikuasai siswa setelah selesai proses belajar mengajar, bagaimana menggunakan apa yang dikuasainya dalam kehidupan sehari-hari, bagaimana prosedur yang harus diikuti atau kegiatan yang harus dilakukan siswa agar mencapai tujuan pembelajaran dan sebagainya. 7. Kegiatan belajar yang dibagi-bagi menjadi langkahlangkah kecil dan disertai umpan balik menyelesaikan tiap langkah, akan membantu siswa. Implikasinya, adalah guru harus menganalisa pengalaman belajar siswa menjadi kegiatan-kegiatan kecil, disertai latihan-latihan dan refleksi terhadap hasilnya. Kebutuhan memecah materi yang kompleks menjadi kegiatan- kegiatan kecil dapat dikurangi dengaan mewujudkannya dalam suatu model. Implikasinya adalah penggunaan media dan metode pembelajaran yang dapat menggambarkan materi yang kompleks kepada siswa, model, realita, film, program video komputer, drama, demontrasi dan lain-lain. 9. Keterampilan tingkat tinggi terbentuk dari keterampilan dasar yang lebih sederhana. Implikasinya adalah tujuan pembelajaran harus dirumuskan dalam bentuk hasil belajar yang opperasional. Demontrasi atau model yang digunakan harus dirancang agar dapat menggambarkan dengan jelas komponenkomponen yang termasuk dalam perilaku /keterampilan yang kompleks itu.

Belajar akan lebih cepat, efesien dan menyenangkan bila siswa diberi informasi tentang kualitas penampilannya dan cara meningkatkannya. Urutan pembelajaran harus dimulai dari yang sederhana secara bertahap menuju pada yang lebih kompleks; kemajuan siswa dalam menyelesaikan pembelajaran harus diinformasikan kepadanya. Perkembangan dan kecepatan belajar siswa sangat bervariasi, ada yang maju dengan penguasaan siswa terhadap materi prasyarat sebelum mempelajari materi pembelajaran selanjutnya; siswa mendapat kesempatan maju menurut kecepatan masing masing.

Dengan persiapan, siswa dapat membangkitkan kemampuan mengorganisasikan kegiatan belajarnya sendiri dan menimbulkan umpan balik bagi dirinya untuk membuat respon yang benar. Implikasinya adalah pemberian kemungkinan bagi siswa untuk memilih waktu, cara dan sumber - sumber disamping yang telah ditentukan, agar dapat membuat dirinya mencapai tujuan pembelajaran. Rangkaian prinsip -prinsip manajemen pembelajaran tersebut akan lebih sempurna jika dipadukan, disandingkan dengan perasaan Gagne (1977; 198) yang dilantunkan Munandir, bahwa prinsip pembelajaran meliputi hal-hal berikut ini: Menarik perhatian (gaining attention) ; dalam hal ini, seorang guru harus mampu menyuguhkan materi yang bisa siswa untuk belajar, sehingga minat siswa bangkit dan terhampar dijiwanya. Misalnya memberikan sesuatu hal yang baru, yang berbau aneh, topik yang sedang hangat. Bahkan mungkin saja menyodorkan masalah yang terbungkus dengan hal-hal yang kontradiksi.

Memberitahu pembelajar mengenai tujuan belajar (informing learner of the objectives); maknanya, siswa hendaknya diberitahu tentang pencapaian yang diharapkan dalam hasil belajar. Pengaruh pemberian kepada siswa tentang hasil belajar adalah untuk mencocokan unjuk kerjanya.

Merancang ingatan kembali pengetahuan sebelumnya (stimulating recall or prior 
learning) ; dalam hal ini, siswa diajak dan disentuh hatinya, otaknya, perasaannya, jiwanya untuk mengingat kembali mata pelajaran yang telah bersemayam dalam fikirannya.

Menyajikan material stimulus; (presenting the stimulus); dalam hal ini, guru menyampaikan dengan penuh perasaan tentang bait-bait pembelajaran yang telah diurai dan direncanakan sebelumnya.

Memberikan bimbingan belajar (providing learner guidance); dalam hal ini, guru harus mampu membimbing, mengarahkan dengan penuh kelembutan terhadap sosok siswa, agar siswa memiliki pemahaman yang lebih baik dalam pelaksanaan proses pembelajaran.

Memunculkan unjuk kerja siswa (eliciting performance), berarti siswa digiring dengan penuh kedamaian untuk menunjukan kemampuannya dalam penguasaan materi pelajaran yang telah disantapnya selama dalam pembelajaran.

Memberikan balikan (providing feedback); menyampaikan kepada siswa tentang unjuk kerja yang telah dilakukan. Dilakukan untuk melihat ketepatan penampilan siswa. Menilai unjuk kerja (assesing performance); ini merupakan kewajiban siswa untuk menyelesaikan tugas yang disuguhkan guru. Sehingga dapat dilihat dan diketahui sebesar dan seluas apa yang telah dikuasi siswa dalam tujuan pembelajaran.

Meningkatkan retensi dan pengalihan belajar (enchancing retention and transfer). Inilah babak akhir perjalanan prinsip pembelajaran Gagne, siswa dirangsang untuk mengingat masa lalu dalam pembelajaran yang telah dipelajarinya, dan siswa diajak untuk mentransfer dan membubuhkannya dalam lembaran-lembaran rangkuman, bahkan, siswa diminta untuk menampilkan kembali apa yang selama ini dipelajari dalam kehidupannya di sekolah.

Terasa lengkap dan sempurnanya sudah prinsip pembelajaran yang tertulis dan tercatat di atas. Tidak ada lagi keraguan, tidak ada lagi kegalauan yang menghimpit fikiran dan perasaan. Karenanya untuk menciptakan kekuatan pembalajaran yang efektif dan efesien bagi siswa, perlu diupayakan pengembangan prinsip-prinsip pembelajaran yang telah tertulis dalam lembaran kertas bisu tersebut di atas.

Berdasarkan hal tersebut, konsep diri dan prestasi akademik dapat tercapai dengan baik apabila manajemen pembelajaran di suatu kelas atau lembaga itu berjalan baik. Manajemen pembelajaran yang baik tidak lepas dari kualitas sumber daya manusia, pendidikan memegang peran yang sangat penting dalam proses peningkatan kualitas sumber daya manusia. Peningkatan kualitas pendidikan merupakan suatu proses yang terintegrasi dengan proses peningkatan kualitas sumber daya manusia itu sendiri. Peningkatan kualitas sumber daya manusia di kampus terkhusus untuk mahasiswa dapat terlihat dari pencapaian prestasi akademik dan konsep diri yang baik.

Menyadari pentingnya proses peningkatan kualitas sumber daya manusia, maka pemerintah bersama kalangan swasta bersama-sama telah dan terus berupaya mewujudkan amanat tersebut melalui berbagai usaha pembangunan pendidikan yang lebih berkualitas, antara lain melalui pengembangan dan perbaikan kurikulum dan sistem evaluasi, perbaikan sarana pendidikan, pengembangan dan pengadaan materi ajar, pelatihan dan peningkatan kualifikasi dosen, sera peningkatan mutu manajemen perguruan tinggi.

Pendidikan yang berkualitas dapat menunjuk kepada kualitas proses dan kualitas produk. Pendidikan disebut bermutu dari segi proses jika proses belajar mengajar berlangsung secara efektif, peserta didik mengalami proses pembelajaran yang bermakna, dan ditunjang oleh sumber daya (manusia, dana, sarana, prasarana) yang wajar. Tentu saja hal ini juga dipengaruhi oleh kualitas masukannya. Logikanya, proses pendidikan yang berkualitas akan menghasilkan produk yang berkualitas pula.

Konsep diri dengan prestasi akademik telah disinggung pula dalam teori bahwa konsep diri individu turut mempengaruhi pencapaian prestasi akademiknya. prestasi akademik sendiri merupakan hasil pelajaran yang yang diperoleh dari kegiatan persekolahan yang bersifat kognitif dan biasanya ditentukan melalui pengukuran dan penilaian. Konsep diri berhubungan motivasi yang dimiliki seseorang, semakin baik konsep diri yang dimiliki maka semakin baik tinggi motivasi yang dimiliki untuk mencapai tujuan yaitu prestasi akademik yang tinggi. Peserta didik dengan konsep diri yang buruk akan cenderung kehilangan motivasi dan minat yang pada akhirnya berdampak pula pada prestasi akademik.

Berdasarkan hal tersebut, maka perlu dilakukan penelitian terkait). Hubungan Konsep Diri Dengan Prestasi Akademik Mahasiswa S1 Keperawatan Sekolah Tinggi Ilmu Kesehatan Aisyah Pringsewu. 


\section{B. METODE PENELITIAN}

Jenis penelitian ini adalah penelitian survei analitik. dengan menggunakan pendekatan crossectional. Variabel dalam penelitian ini terdiri dari variabel independen dan variabel dependen. Populasi yang digunakan dalam penelitian ini adalah seluruh mahasiswa semester VIII program studi S1 Keperawatan sebanyak 47, menggunakan tekhnik total sampling dalam penelitian ini. Lokasi penelitian ini dilakukan di Sekolah Tinggi Ilmu

Kesehatan Aisyah Pringsewu Pada Program Studi S1 Keperawatan. Analisis data dengan analisis univariat untuk melihat distribusi dan frekuensi variabel dependen dan independen dan analisis bivariat untuk mengetahui hubungan antara konsep diri dengan prestasi akademik.

\section{HASIL DAN PEMBAHASAN}

Tabel 1. Distribusi Frekuensi Responden Berdasarkan Konsep Diri

\begin{tabular}{ccc}
\hline Indikator & Frekwensi & $\begin{array}{c}\text { Persentase } \\
(\mathbf{\%})\end{array}$ \\
\hline Positif & 31 & 65,9 \\
Negatif & 16 & 34,1 \\
\hline Jumlah & $\mathbf{4 7}$ & $\mathbf{1 0 0}$ \\
\hline
\end{tabular}

Tabel 2. Distribusi Frekuensi Responden Berdasarkan Prestasi Akademik

\begin{tabular}{lcc}
\hline Indikator & Frekuensi & $\begin{array}{c}\text { Persentase } \\
(\mathbf{\%})\end{array}$ \\
\hline Baik & 33 & 70,2 \\
$\begin{array}{l}\text { Kurang } \\
\text { baik }\end{array}$ & 14 & 29,8 \\
\hline Jumlah & $\mathbf{4 7}$ & $\mathbf{1 0 0}$ \\
\hline
\end{tabular}

Tabel diatas menunjukan bahwa sebagian besar responden yang memiliki konsep diri dalam kategori positif yaitu sebanyak 31 responden $(65,9 \%)$, dimana terdapat 26 responden $(83,9 \%)$ mendapat Prestasi Akademik baik, dan 5 responden $(16,1 \%)$ psikologis, sosial, emosional, aspirasi, dan prestasi yang mereka capai. Konsep diri bukanlah faktor hereditas, melainkan faktor yang dipelajari Berdasarkan tabel diatas dapat diketahui bahwa dari 47 responden, ditemukan 31 responden $(65,9 \%)$ dengan konsep diri positif.

Konsep diri dari perspektif partisipan sendiri dan perspektif orang lain menurut diri partisipan. Partisipan mengungkapkan konsep diri dari perspektif orang lain berasal dari penilaian yang pernah dikatakan oleh orang lain kepada partisipan. Penilaian tersebut berupa pujian, saran atau kritik yang didapat oleh para partisipan sehingga partisipan dapat menjelaskan konsep diri yang dilihat dari perspektif orang lain.

Tabel 3. Implementasi manajemen pembelajaran terhadap Konsep Diri dan Prestasi Akademik Mahasiswa S1 Keperawatan Semester VIII

\begin{tabular}{|c|c|c|c|c|c|c|}
\hline \multirow{3}{*}{$\begin{array}{c}\text { Konsep } \\
\text { Diri }\end{array}$} & \multicolumn{4}{|c|}{ Prestasi Akademik } & \multirow{2}{*}{\multicolumn{2}{|c|}{ Total }} \\
\hline & \multicolumn{2}{|c|}{ BAIK } & \multicolumn{2}{|c|}{$\begin{array}{c}\text { Kurang } \\
\text { Baik }\end{array}$} & & \\
\hline & $\mathrm{N}$ & $\%$ & $\mathrm{~N}$ & $\%$ & $\mathrm{~N}$ & $\%$ \\
\hline Positif & 26 & 83,9 & 5 & 16,1 & 31 & 65,9 \\
\hline Negatif & 7 & 43,8 & 9 & 56,2 & 16 & 34,1 \\
\hline Jumlah & 33 & 70,2 & 14 & 29,8 & 47 & 100 \\
\hline
\end{tabular}

Berdasarkan tabel di atas dapat diketahui bahwa 47 responden ditemukan 31 responden $(65,9 \%)$ dengan konsep diri positif (Hurlock, 2006), mengartikan konsep diri sebagai gambaran mendapat Prestasi Akademik kurang baik, dan hanya 16 responden $(34,1 \%)$ yang memiliki konsep diri negatif, dimana sebanyak 7 responden (43,8\%) mendapat Prestasi Akademik baik, dan sebanyak 9 responden $(56,2 \%)$ mendapat Prestasi Akademik kurang baik.

Berdasarkan hasil uji statistik chi square diketahui bahwa $p$ value yaitu 0,008 lebih kecil dari 0,05 ( $p$ value $<0,05)$, sehingga Ho di tolak dan Ha Diterima. Hal ini menunjukan bahwa terdapat keterhubungan antara implementasi manajemen pembelajaran, konsep diri dengan Prestasi Akademik pada Mahasiswa S1 Keperawatan Semester 8 di Stikes Aisyah Pringsewu Tahun 2016 dengan keeratan hubungan $(O R=6,500)$, yang menunjukkan bahwa mahasiswa yang memiliki konsep diri positif $6 \mathrm{x}$ lebih berpotensi untuk mendapatkan prestasi akademik yang baik.

Tarwoto \&Wartonah, (2006) faktorfaktor yang dapat memengaruhi konsep diri adalah sebagai berikut : Tingkat perkembangan dan kematangan Budaya, Sumber eksternal dan internal, Pengalaman sukses dan gagal, Stresor, Usia, keadaan sakit, dan trauma.

Konsep diri bukanlah merupakan faktor keturunan, melainkan faktor yang terbentuk dari pengalaman dan hubungan individu dengan orang lain. Hasil penelitian pada mahasiswa S1 Keperawatan STIKes Aisyah Pringsewu berdasarkan kategori konsep diri, terdapat beberapa responden yangmemiliki konsep diri negatif. Hal ini disebabkan karena 
beberapa responden kurang positif dalam mengenal dirinya sendiri.

Sobur (2006) menyatakan bahwa ciri individu yang memiliki keinginan berprestasi tinggi adalah, berprestasi dihubungkan dengan seperangkat standar. Seperangkat standar tersebut dihubungkan dengan prestasi orang lain, prestasi diri sendiri yang lampau, serta tugas yang harus dilakukan. Memiliki tanggung jawab peribadi terhadap kegiatan-kegiatan yang dilakukan. Adanya kebutuhan untuk mendapatkan umpan balik atas pekerjaan yang dilakukan sehingga dapat diketahui dengan cepat hasil yang diperoleh dari kegiatannya, lebih baik atau lebih buruk. Menghindari tugastugas yang sulit atau terlalu mudah, akan tetapi memilih tugas yang tingkat kesulitannya sedang. Inovatif, yaitu dalam melakukan suatu pekerjaan dilakukan dengan cara yang berbeda, efisien dan lebih baik dari pada sebelumnya. Hal ini dilakukan agar individu mendapatkan cara yang lebih baik dan menguntungkan dalam pencapaian tujuan. Tidak menyukai keberhasilan yang bersifat kebetulan atau karena tindakan orang lain, dan ingin merasakan kesuksesan atau kegagalan disebabkan oleh tindakan individu sendiri.

Untuk melihat kemampuan akademik seseorang dapat dilihat dari prestasi akademiknya, antara lain Indeks Prestasi Akademik (IPK). Dari hasil penelitian pada mahasiswa S1 Keperawatan semester 8 di STIKes Aisyah Pringsewu, menunjukkan beberapa mahasiswa mendapat IPK kurang baik, ini disebabkan karena beberapa faktor salah satunya konsep diri yang negatif.

Hasil penelitian mengenai implementasi manajemen pembelajaran terhadap konsep diri dan Prestasi Akademik Mahasiswa S1 Keperawatan Semester 8 di Stikes Aisyah Pringsewu Tahun 2016 diperoleh hasil sebagai berikut : Hasil penelitian didapatkan bahwa ada keterkaitan antara konsep diri dengan prestasi akademik ( $p$ value $=0,008<0,05$ ). Bahwa ada keterkaitan antara konsep diri dengan Prestasi akademik mahasiswa S1 Keperawatan Semester 8 di Stikes Aisyah Pringsewu Tahun 2016.

Hasil penelitian ini sesuai dengan pendapat yang dikemukakan Soemanto (2006), bahwa faktor yang dapat mempengaruhi prestasi akademik adalah konsep diri, keterkaitan antara tingkah laku dan akibatnya (locus of control), kecemasan yang dialami, dan motivasi hasil belajar dan selain itu manajemen pembelajaran yang baik juga menjadi pendukung dalam hal tersebut. Menurut Combs et al (dalam Soemanto, 2006) para pendidik telah menjadi semakin sadar akan dampak konsep diri (self-concept) dan harga diri (self-esteem) terhadap tingkah laku anak di dalam kelas dan terhadap prestasinya.

keterhubungan antara konsep diri dengan prestasi akademik telah disinggung pula dalam teori bahwa konsep diri individu turut mempengaruhi pencapaian prestasi akademiknya dan selain itu manajemen pembelajaran yang baik turut menjadi pendukung dalam hal tersebut. Prestasi akademik sendiri merupakan hasil pelajaran yang yang diperoleh dari kegiatan persekolahan yang bersifat kognitif dan biasanya ditentukan melalui pengukuran dan penilaian.

\section{KESIMPULAN}

Berdasarkan hasil penelitian disimpulkan bahwa implementasi manajemen pembelajaran terhadap konsep diri dan prestasi akademik mahasiswa semester VIII Sekolah Tinggi Ilmu Kesehatan AISYAH Pringsewu yang diketahui bahwa ( $p$ value $=0,008<0,05$ ) sehingga Ho di tolak. Hal ini menunjukan bahwa terdapat hubungan yang signifikan antara Konsep Diri dengan Prestasi Akademik mahasiswa S1 keperawatan semester 8 di STIKes Aisyah Pringsewu Lampung tahun 2016, dengan keeratan hubungan $(O R=6,500)$, yang menunjukan bahwa mahasiswa yang memiliki konsep diri positif 6x lebih berpotensi untuk mendapatkan prestasi akademik yang baik.

\section{DAFTAR PUSTAKA}

Alex Sobur. 2006. Semiotika Komunikasi. Bandung. Remaja: Rosdakarya.

Alimul. 2009. Metode Penelitian Keperawatan dan Tekhnik Analisa Data, Salemba Medika. Jakarta.

Bumi Aksara. Sujadi. 2012. Membuat Siswa Aktif Belajar. (73 Cara Belajar Mengajar Dalam Kelompok) Bandung. Mandar Maju.

Hurlock, Elizabeth, B., Psikologi Perkembangan, Erlangga, Jakarta, 2006.

Prospect Solihatin, Etin \& Raharjo. 2007. Cooperatif Learning. Analisis Model Pembelajaran IPS. Jakarta.

Sanjaya, Wina.2007. Strategi Pembelajaran (berorientasi Standar Proses Pendidikan). Jakarta. Kencana. 
Siregar, Evelin \& Nara, Hartini.2010. Teori Belajar dan Pembelajaran. Jakarta. Ghalia Indonesia.

Sistem Kesehatan Dasar .2004. Jakarta. Badan Penelitian dan Pengembangan. Kesehatan. Departemen Kesehatan Republik Indonesia.

Sodiq, Akhmad. 2009. Metodologi Pembelajaran Agama Islam. Ciputat. FITK. UIN . Jakarta.

Soemanto, Wasty. 2006. Psikologi Pendidikan. Jakarta: Rineka Cipta.

Sumargi, A.M; Kurniawan.Y; Sasongko. 2008. Apa Yang Diketahui Anak-Anak Sekolah Dasar Tentang Keselamatan Dirinya: Studi Pendahuluan Tentang Pemahaman Keselamatan Diri. Jurnal Penelitian Psikologi, 2 (4), 1-9. Fakultas Univertas Katolik Widya Mandala Surabaya.

Sutikno, Sobbry. 2008. Belajar dan Pembelajran. Bandung.

Tarwoto \& Wartonah. 2006. Kebutuhan Dasar Manusia Dan Proses Keperawatan. Edisi Ke-3. Jakarta: Salemba Medika

Wahab, Abdul Aziz. 2007. Metode dan Model-Model Mengajar IPS. Bandung. Alfabetha. 